\title{
Tadalafil combined with remote ischemic preconditioning in the prevention of renal ischemia/reperfusion injury
}

\section{Tadalafil combinado com pré-condicionamento isquêmico remoto na prevenção de lesão por isquemia/reperfusão renal}

Ítalo Medeiros Azevedo ${ }^{1}$, Gabriela Vieira da Silva², Aristela Sinara Varela Constantino de Medeiros², Ariadne Sibelle Varela Constantino de Medeiros Dumaresq de Souza ${ }^{2}$, Rosana Karla Aires de Macêdo ${ }^{3}$, Aldo Cunha Medeiros ${ }^{4}$

1. Fellow PhD degree, Postgraduate Program in Health Sciences, UFRN, Natal-RN, Brazil.

2. Graduate student, Medical School, Federal University of Rio Grande do Norte (UFRN), NatalRN, Brazil.

2. Veterinarian, UFRN, Natal-RN, Brazil.

5. PhD, Full Professor, Chairman, Nucleus of Experimental Surgery, UFRN, Natal-RN, Brazil.

Study performed at Department of Surgery, Federal University of Rio Grande do Norte (UFRN), Brazil.

Financial support: CNPq.

Conflict of interest: The authors declare that they have no conflict of interest.

Correspondence address: Department of Surgery, Federal University of Rio Grande do Norte, at Ave. Nilo Peçanha 620, Natal, RN, Brazil. E-mail: cirurgex.ufrn@gmail.com

Submitted: May 16, 2018. Accepted, after review: August 13, 2018.

\section{ABSTRACT}

PURPOSE: This study aimed to evaluate whether the combination of tadalafil treatment and remote ischemic preconditioning may provide protection against ischemia reperfusion injury $(\mathrm{I} / \mathrm{R})$ in kidneys of rats. METHODS: Twenty-four male Wistar rats weighing 280-300g were randomly divided into 3 groups: Group 1 - (control), only right nephrectomy was performed. No treatment with tadalafil. Group II - Left renal ischemia, right nephrectomy, without remote preconditioning, treatment with tadalafil (1.0 $\mathrm{mg} / \mathrm{kg}$, oral). Group III - Left renal ischemia, right nephrectomy, with remote preconditioning, treatment with tadalafil. RESULTS: $24 \mathrm{~h}$ after, urea and creatinine dosage and histopathology of the ischemic kidneys were performed. In the left kidney of control group rats, a higher degree of cellular necrosis was observed when compared to the tadalafil group, with and without remote preconditioning. On the preconditioning + tadalafil group rats, there was a significant reduction in histological parameters when compared to the Ischemia + tadalafil group rats $(p<0.05)$. In group III, comparing to other groups, a significant improvement of the left kidney function was observed, through the lower values of the urea and creatinine dosages. 
Tadalafil combined with remote ischemic preconditioning in the prevention of renal ischemia/reperfusion injury.

Azevedo IM, et al.

CONCLUSION: This study demonstrated protective effects of remote preconditioning + tadalafil in an experimental model of renal $I / R$ in the rat. The results demonstrated that a single dose of tadalafil prior to renal $I / R$ attenuated the histopathological lesions, especially cellular necrosis, and renal function tests.

Keywords: Ischemia. Reperfusion. Kidney. Tadalafil. Ischemic Preconditioning.

\section{RESUMO}

OBJETIVO: Estudo com o objetivo de avaliar se a combinação de tratamento com tadalafil e pré-condicionamento isquêmico remoto pode fornecer proteção contra lesão por isquemia e reperfusão renal (I/R) em ratos. MÉTODOS: Vinte e quatro ratos Wistar machos pesando 280- 300g foram divididos aleatoriamente em 3 grupos: Grupo 1 (controle), foi realizada apenas a nefrectomia direita. Sem tratamento com tadalafil. Grupo II - Isquemia renal esquerda, nefrectomía direita, sem pré-condicionamento remoto, tratamento com tadalafil $(1,0 \mathrm{mg} / \mathrm{kg}$, via oral). Grupo III - Isquemia renal esquerda, nefrectomía direita, com pré-condicionamento remoto, tratamento com tadalafil. Após 24 horas de observação foi feita dosagem de ureia e creatinina e histopatologia do rim isquemiado. RESULTADOS: Nos rins esquerdos dos animais do grupo controle foi observado um maior grau de necrose celular quando comparados com o grupo tratado com o tadalafil, com e sem precondicionamento. Quando foi acrescentado o precondicionamento + tadalafil houve significativa redução dos parâmetros histológicos comparando-se com o grupo de animais Isquemia + tadalafil $(p<0,05)$. No grupo III, comparando-se os demais grupos, observou-se significativa melhora da função do rim esquerdo, através dos valores mais baixos das dosagens de ureia e creatinina. CONCLUSÃO: Em conclusão, este estudo demonstrou efeitos protetores do pré-condicionamento remoto + tadalafil em modelo experimental de lesão renal por I/R no rato. Os resultados demonstraram que uma dose única de tadalafil antes da I/R renal atenuou as lesões histopatológicas, especialmente a necrose celular, e provas de função renal observadas após I/R.

Descritores: Isquemia. Reperfusão. Rim. Tadalafil. Precondicionamento Isquêmico.

\section{INTRODUCTION}

Due to the high energy demand for the functions it performs, and an important microvascular network, the kidney is highly sensitive to ischemia/reperfusion injury $(\mathrm{I} / \mathrm{R})$, which is a major cause of acute renal failure, in renal artery stenosis, in 
Tadalafil combined with remote ischemic preconditioning in the prevention of renal ischemia/reperfusion injury.

Azevedo IM, et al.

transplantation and renal surgery ${ }^{1}$. In addition, renal I/R damage is associated with delayed graft function after transplantation, complicates shock, cardiac and aortic surgery and is a major cause of cardiovascular morbidity and mortality ${ }^{2,3}$.

Although I/R renal injury is an important and common clinical problem, current strategies to reduce it are ineffective and new therapies are needed. I/R kidney damage is a common and important cause of acute kidney failure. It is inevitably associated with transplantation, involves both the adaptive immune response, and causes subsequent inflammation. The attraction and transmigration of cells from the immune system to the interstitium is associated with increased vascular permeability and loss of endothelial cells and integrity of the tubular epithelial cell ${ }^{3,4}$.

The consequences of I/R injury are restriction of blood supply to an organ, followed by restoration of blood flow and re-oxygenation. The inevitable lesions can occur after infarction, sepsis and organ transplantation, and this phenomenon exacerbates tissue damage, initiating an inflammatory cascade ${ }^{4,5}$. In the kidney, I/R injury contributes to the pathological condition called acute renal injury, which is a clinical syndrome with rapid renal dysfunction and high mortality rates ${ }^{6}$. The pathophysiology of renal I/R is complex, and some important pathological changes such as neutrophil activation, release of reactive oxygen species and other inflammatory mediators, including adhesion molecules and a variety of cytokines, are involved. Surveys have shown beneficial effects of different agents in the fight against I/R damage, for example, doxycycline by reducing the level of proinflammatory cytokines ${ }^{7,8}$, leptin by reducing levels of tumor necrosis factor alpha (TNF- $\alpha$ ) and increased levels of nitrites $^{9}$, levosimendan as antioxidant and mechanisms related to nitrous oxide $(\mathrm{ON})^{10}$, iloprost by suppression of lipid peroxidation ${ }^{11}$ and ascorbic acid by elimination of free radicals (antioxidant) ${ }^{12}$, and others.

Data on the types of cells involved typically vary ${ }^{13-15}$. It is well known that increased influx of neutrophils, $T$ and $B$ lymphocytes, as well as monocytes/macrophages, which contributes significantly to the pathogenesis of acute kidney injury ${ }^{16,17}$.

In 1993, the phenomenon of remote ischemic preconditioning (RIPC) was first demonstrated in a canine model of myocardial infarction, where the preconditioning of 
Tadalafil combined with remote ischemic preconditioning in the prevention of renal ischemia/reperfusion injury.

Azevedo IM, et al.

a vascular territory at a distance conferred protection to the vascular bed in the heart ${ }^{19}$. Other models has been described ${ }^{20}$. In rats, hind limb ischemia by brief clamping of the abdominal aorta reduced oxidative stress after 45 minutes of renal ischemia in rats ${ }^{21}$. Remote ischemic limb preconditioning (which has been shown to be effective for the heart and skeletal muscle) has great clinical advantages because the limb is easy to manipulate and relatively resistant to injury by I/R. The underlying mechanisms of RIPC and its signaling pathways remain obscure ${ }^{19}$. Some neurogenic factors and the release of biochemical messengers have been implicated ${ }^{22-24}$.

Inhibitors of forfodiesterases (PDEs) are compounds that inhibit or antagonize the biosynthesis or actions of PDEs. They are widely used for the treatment of pulmonary arterial hypertension and erectile dysfunction in men ${ }^{25}$. These vasodilatory and inotropic agents have protective effects on vascular structures and myocardial muscles ${ }^{26-28}$. The effects of these drugs have been studied especially in I/R injury. Tadalafil and sildenafil citrate have been widely used to treat erectile dysfunction and also several other diseases such as hypertension, prostatic hyperplasia and coronary heart disease in the clinic ${ }^{28,34}$. On the other hand, in experimental studies, the protective effects of PDE5 inhibitors on I/R injury have been individually proven in several tissues, such as myocardium ${ }^{31}$, spinal $\operatorname{cord}^{32}$, brain ${ }^{29}$ and kidney ${ }^{33}$.

Based on these informations, we hypothesized that remote ischemic preconditioning associated with tadalafil may influence kidney ischemia and reperfusion in an experimental model in rats.

\section{METHODS}

\section{Animals}

The protocol was submitted for analysis and approved by the Institutional Ethics Committee on Animal Use (CEUA/HUOL) (Protocol 02/2018). All experiments in this study were performed according to the animal research guidelines of Brazilian Law $11,497 / 2008$. Male Wistar rats were housed in individual polypropylene cages receiving food for rodents and water ad libitum at the Nucleus of Experimental Surgery-UFRN, Brazil. 
Tadalafil combined with remote ischemic preconditioning in the prevention of renal ischemia/reperfusion injury.

Azevedo IM, et al.

\section{Surgical Procedures}

All surgical procedures were performed using aseptic surgical techniques. Anesthesia was performed with ketamine $80 \mathrm{mg} / \mathrm{kg}$ and xylazine $7 \mathrm{mg} / \mathrm{kg}$ intraperitoneal. Remote ischemic preconditioning (RIPC) for short periods of ischemia and reperfusion of the right hind limb was induced by application of tourniquet with pressure higher than arterial pressure around the proximal portion of the thigh of the animals in three cycles of $10 \mathrm{~min} / 10 \mathrm{~min}$.

After the last 10 min of the RIPC, the rats were subjected to laparotomy and the left renal artery was isolated and clamped for 30 minutes. After 30 min of renal ischemia the vascular microclamp was removed and renal reperfusion will be observed. The right kidney was nephrectomized. In the immediate postoperative period analgesia was performed with meperidine, $10 \mathrm{mg} / \mathrm{kg}$ body weight administered s.c. On the 1st postoperative day, euthanasia was performed with anesthetic overdose (thiopental 100 $\mathrm{mg} / \mathrm{kg}$ associated with lidocaine, i.p).

\section{Experimental design}

Twenty-four male Wistar rats weighing 280-300g were randomly divided into 3 groups, each with six animals. Tadalafil (Eli Lilly origin from Brazil) was dissolved in saline solution and administered according to the groups as a single dose $(1 \mathrm{mg} / \mathrm{kg})$ through gavage $60 \mathrm{~min}$ prior to surgical procedures.

Under anesthesia, an incision was made in the midline of the upper abdomen and the left renal pedicle vessels were isolated using minimal dissection.

Group I - Left renal ischemia and right nephrectomy were performed. No treatment with tadalafil.

Group II - Left renal ischemia, right nephrectomy, without remote preconditioning, tadalafil treatment

Group III - Left renal ischemia, right nephrectomy, with remote preconditioning, treatment with tadalafil. 
Tadalafil combined with remote ischemic preconditioning in the prevention of renal ischemia/reperfusion injury.

Azevedo IM, et al.

\section{Biochemical analysis}

Whole blood ( $5 \mathrm{~mL}$ ) was collected by cardiac puncture for dosages. Serum levels of urea and creatinine were measured. The blood samples were collected in dry tubes, centrifuged and the serum stored in a $-20^{\circ} \mathrm{C}$ freezer until the tests were carried out. The parameters were measured using commercial Labtest kits, Belo Horizonte, MG, Brazil, according to the manufacturer's recommendations, using the Labmax240 equipment. The left kidney was removed for examination.

\section{Histopathological evaluation}

The histopathological evaluation was performed in the kidneys for the quantitative analysis of the histological pattern of tissue changes after ischemia, and were graded by scores, as shown in table 1 . The score rank was applied for microscopic changes compatible with acute tubular necrosis: tubular light dilatation, tubular cell vacuolization, intratubular cylinders and tubular cell necrosis

Table 1 - Scores used for histopathological evaluation

\begin{tabular}{c|l}
\hline SCORE & \multicolumn{1}{|c}{ HISTOPATHOLOGICAL PATTERN } \\
\hline 0 & Normal \\
0.5 & Small injured focal areas \\
1 & $<10 \%$ of the injured cortical area \\
2 & 10 to $25 \%$ of the damaged cortical area \\
3 & 25 to $75 \%$ of the damaged cortical area \\
4 & $>75 \%$ of injury \\
\hline
\end{tabular}

Each kidney had correspondent scores determined in duplicate by the same observer, who was not aware of which groups the slides belonged to. The experiment was completely randomized.

\section{Statistical treatment}

Statistical analysis was done using the Statistical Package for Social Sciences, version 20.0 for Windows, (SPSS, IBM, USA). Histological damages between the groups 
Tadalafil combined with remote ischemic preconditioning in the prevention of renal ischemia/reperfusion injury.

Azevedo IM, et al.

were compared by the Tukey and Mann-Whitmann tests. The $p$ value $<0.05$ was considered statistically significant.

\section{RESULTS}

\section{Histopathological data}

In the left kidney of the ischemia group (24 hours post-ischemia), a higher degree of cellular necrosis ( $\mathrm{CN}$ ) was observed when compared to the Tadalafil group, with and without preconditioning. When preconditioning was added to tadalafil treatment, there was a significant reduction of histological scores when compared with the group of animals Ischemia + tadalafil. $(p<0.05)$. These data are summarized in table 2.

Table 2 - Descriptive data and respective statistical test of the histopathological changes in the left kidney. Right nefrectomy was done in all rats; comparative data between the analyzed groups.

\begin{tabular}{|c|c|c|c|}
\hline \multirow{2}{*}{$\begin{array}{l}\text { Histomorphometric } \\
\text { parameter }\end{array}$} & \multicolumn{3}{|c|}{ Left kidney } \\
\hline & Ischemia & $\begin{array}{l}\text { Ischemia + Tadalafil } \\
\text { No preconditioning }\end{array}$ & $\begin{array}{l}\text { Ischemia + tadalafil } \\
\text { with preconditioning }\end{array}$ \\
\hline TLD & $1.51 \square 0.09^{a}$ & $2.55-0.07^{a}$ & $1.9=0.04^{a}$ \\
\hline CV & $3.29=0.43^{a}$ & $1.77=0.25^{a}$ & $1.38=0.11^{\mathrm{a}}$ \\
\hline IC & $3.82 \square 0.33^{a}$ & $2.18 \square 0.38^{a}$ & $1.25 \square 0.09^{a}$ \\
\hline $\mathrm{CN}$ & $3.39-1.29^{a}$ & $1.27=0.04^{a}$ & $1.10=0.03^{a}$ \\
\hline
\end{tabular}

Average Standard Deviation*

Repeated equal letters mean significant difference between groups (significance level of 5\%). TLD Tubular Light Dilation; CV - Cellular Vacuolization; IC - Intra-tubular cylinders; CN - Cell Necrosis.

Regarding cell vacuolization (CV) and intratubular cylinders (IC), there was a greater renal impairment in the ischemia group rats, with a statistically significant difference comparing with the other groups. A greater dilation of the tubular lumen in tadalafil treated animals was demonstrated when compared to the controls, characterizing a significant difference $(p<0.05)$. 
Tadalafil combined with remote ischemic preconditioning in the prevention of renal ischemia/reperfusion injury.

Azevedo IM, et al.

Table 3 - Data described and respective statistical test of urea and creatinine dosages, comparing the groups.

\begin{tabular}{lccc}
\hline \multirow{2}{*}{ Dosing parameter } & \multicolumn{3}{c}{ GROUPS } \\
\cline { 2 - 4 } & Ischemia & $\begin{array}{c}\text { Ischemia + Tadalafil } \\
\text { No preconditioning }\end{array}$ & $\begin{array}{c}\text { Ischemia + tadalafil } \\
\text { With preconditioning }\end{array}$ \\
\hline UREA & $53.2 \pm 7.3^{\mathrm{b}}$ & $49.18 \pm 4.75^{\mathrm{a}}$ & $35.2 \pm 4.31^{\mathrm{a}, \mathrm{b}}$ \\
CREATININE & $3.04 \pm 0.36^{\mathrm{a}}$ & $1.52 \pm 0.25^{\mathrm{a}}$ & $1.14 \pm 0.15^{\mathrm{a}}$ \\
\hline
\end{tabular}

Mean Standard Deviation

*Repeated equal letters mean significant difference between groups (significance level of 5\%).

In the renal ischemia + tadalafil + preconditioning group, a significant improvement of the left kidney function was observed, as shown by the urea and creatinine values (table 3 ).

\section{DISCUSSION}

Phosphosteresterases (PDE) represent a family of enzymes that regulate the cellular levels of cyclic adenosine monophosphate (cAMP) and cyclic guanosine monophosphate (cGMP) 34,35 . PDE-1 is found in high concentration in vascular smooth muscle cells of the cavernous bodies of the penis, in the smooth muscle cells of peripheral arterial and venous vessels, as well as in the coronary and pulmonary circulation and in the platelets ${ }^{34}$.

Remote ischemic preconditioning has been shown to protect the organs and tissues of IR injury. It involves complex signaling and interactions that activate ATP and adenosine-dependent potassium channels, release adenosine and bradykinin, generate neurohormones, nitric oxide and chemokines, which attenuate the opening of the transition pores of mitochondrial permeability ${ }^{39}$. In this study, we showed that remote ischemic preconditioning protected the kidneys against acute injuries. Renal function and histological integrity of the kidneys were better preserved in preconditioning + treated with tadalafil rats compared to other treatments.

Increased vascular resistance is produced by loss of renal vascular endothelial capacity to release nitric oxide (NO), or an imbalance between NO and endothelin-1 production. At this point, PDE-1 inhibitors can increase the production of cGMP by removing PDE away ${ }^{40}$. They increase NO release and improve endothelial dysfunction ${ }^{41}$. 
Tadalafil combined with remote ischemic preconditioning in the prevention of renal ischemia/reperfusion injury.

Azevedo IM, et al.

In the literature, few studies have examined the effects of PDE inhibitors on renal I/R damage. Chintala et $\mathrm{al}^{42}$ found that a selective cGMP PDE-1 inhibitor, Zaprinast, had antiplatelet effects after $I / R$ in rats. Lledo-Garcia et $\mathrm{al}^{40}$ reported that sildenafil improved the outcome of ischemic kidneys in the immediate posttransplant period. Oruc et $\mathrm{al}^{33}$ revealed that pre-ischemic treatment with sildenafil citrate can significantly attenuate I/R-induced renal injury, thereby decreasing leukocyte infiltration. Although the protective effects of Sildenafil and vardenafil on renal I/R injury have been examined and accepted in several studies, there are rare studies on the effect of tadalafil on renal I/R injury. Tadalafil is a class of mild vasoactive drugs developed for the treatment of erectile dysfunction ${ }^{27}$. The half-lives of sildenafil and vardenafil are $4 \mathrm{~h}$ and that of tadalafil is $17.5 \mathrm{~h}^{43}$. So, this molecule is a good option in the treatment of regulation of the decrease of vascular resistance and ischemia. According to Sesti et $a^{26}$, tadalafil served as a cardioprotector in the configuration of an experimental myocardial infarction.

The effect of tadalafil can be attributed to its effect as a protector in renal tubular cells and the inhibition of leukocyte infiltration in renal tissue ${ }^{44}$. The damage of the renal tubular epithelium plays an active role in the initiation of the inflammatory response ${ }^{45}$. During ischemic periods, renal leukocyte infiltration is activated and increased. Activated neutrophils can release cytokines, reactive oxygen species, proteases, myeloperoxidase, and other enzymes to cause further damage ${ }^{46}$. In our laboratory we demonstrated that Sildenafil had a protective effect in rat kidneys subjected to normothermic I/R, demonstrated by scintigraphy and histomorphometry ${ }^{47}$. Regarding to preconditioning in an other study we concluded in rodent model that morphologically, ischemic preconditioning with short times promoted greater intestinal protection against the IR lesion in rats ${ }^{48}$. Continuing in this field of research, in the present study, the tubular morphology in the tadalafil pre-treated ischemia group and the pre-treated tadalafil + preconditioning I/R group was significantly better than in the only ischemic group. There was also statistical significance when the groups with and without preconditioning were compared. 
Tadalafil combined with remote ischemic preconditioning in the prevention of renal ischemia/reperfusion injury.

Azevedo IM, et al.

\section{CONCLUSION}

This study demonstrated the protective effects of remote preconditioning + tadalafil in an experimental model of renal injury by $I / R$ in the rat. The results of our study demonstrated that a single dose of tadalafil prior to renal I/R attenuated the histopathological lesions and enhanced the renal function after I/R. Cellular necrosis, which can be considered as an important issue in the development of renal injury, has also attenuated with remote preconditioning and administration of tadalafil.

\section{REFERENCES}

1. Safian RD, Textor SC. Renal-artery stenosis. N Engl J Med 2001; 344: 431-42.

2. Perico $\mathrm{N}$, Cattaneo $\mathrm{D}$, Sayegh $\mathrm{MH}$ et al. Delayed graft function in kidney transplantation. Lancet 2004; 364: 1814-27

3. Ojo AO, Held PJ, Port FK et al. Chronic renal failure after transplantation of a nonrenal organ. N Engl J Med 2003; 349: 931-40.

4. Jang $H R, R a b b H$. The innate immune response in ischemic acute kidney injury. Clin Immunol. 2009;130:41-50.

5. Sharfuddin AA, Molitoris BA. Pathophysiology of ischemic acute kidney injury. Nat Rev Nephrol. 2011;7:189-200.

6. Hoste EA, Clermont G, Kersten A, Venkataraman R, Angus DC, De Bacquer D, et al. RIFLE criteria for acute kidney injury are associated with hospital mortality in critically ill patients: a cohort analysis. Crit Care. 2006;10:R73.

7. Kucuk A, Kabadere S, Tosun M, Koken T, Kinaci M, Isikli B, et al. Protective effects of doxycycline in ischemia/reperfusion injury on kidney. J Physiol Biochem. 2009;65:183-91.

8. Ihtiyar E, Yaşar NF, Erkasap N, Köken T, Tosun M, Öner S. Effects of doxycycline on renal ischemia reperfusion injury induced by abdominal compartment syndrome. J Surg Res. 2011;167:113-20.

9. Erkasap S, Erkasap N, Koken T, Kahraman A, Uzuner K, Yazihan N, et al. Effect of leptin on renal ischemiareperfusion damage in rats. J Physiol Biochem. 2004;60:7984.

10. Grossini E, Molinari C, Pollesello P, Bellomo G, Valente G, Mary D, et al. Levosimendan protection against kidney ischemia/reperfusion injuries in anesthetized pigs. J Pharmacol Exp Ther. 2012;342:376-88.

11. Döslüoğlu HH, Aktan AÖ, Yeğen C, Okboy N, Yalçm AS, Yahn R, et al. The cytoprotective effects of verapamil and iloprost (ZK 36374) on ischemia/ reperfusion injury of kidneys. Transpl Int. 1993;6:138- 42. 
Tadalafil combined with remote ischemic preconditioning in the prevention of renal ischemia/reperfusion injury.

Azevedo IM, et al.

12. Korkmaz A, Kolankaya D. The protective effects of ascorbic acid against renal ischemia-reperfusion injury in male rats. Ren Fail. 2009;31:36-43.

13. Thornton MA, Winn R, Alpers CE, Zager RA. An evaluation of the neutrophil as a mediator of in vivo renal ischemic-reperfusion injury. Am J Pathol 1989;135: 50915.

14. Rabb H, Wang Z, Nemoto T, Hotchkiss J, Yokota N, et al. Acute renal failure leads to dysregulation of lung salt and water channels. Kidney Int. 2003; 63:600-6.

15. Ysebaert DK, De Greef KE, Vercauteren SR, Ghielli M, Verpooten GA, et al. Identification and kinetics of leukocytes after severe ischaemia/reperfusion renal injury. Nephrol Dial Transplant 200;15:1562-74.

16. Kinsey GR, Li L, Okusa MD. Inflammation in acute kidney injury. Nephron Exp Nephrol. 2008; 109: e102-e7.

17. Awad AS, Rouse M, Huang L, Vergis AL, Reutershan J, et al. Compartmentalization of neutrophils in the kidney and lung following acute ischemic kidney injury. Kidney Int. 2009; 75: 689-98.

18. Sarelius IH, Kuebel JM, Wang J, Huxley VH. Macromolecule permeability of in situ and excised rodent skeletal muscle arterioles and venules. Am J Physiol Heart Circ Physiol. 2009; 290: H474-H80.

19. Przyklenk K, Bauer B, Ovize $M$ et al. Regional ischemic 'preconditioning' protects remote virgin myocardium from subsequent sustained coronary occlusion. Circulation 1993; 87: 893-9.

20. Atesx $\mathrm{E}$, Gencx $\mathrm{E}$, Erkasap $\mathrm{N}$ et al. Renal protection by brief liver ischemia in rats. Transplantation 2002; 74: 1247-51.

21. Lazaris AM, Maheras AN, Vasdekis SN et al. Protective effect of remote ischemic preconditioning in renal ischemia/reperfusion injury in a model of thoracoabdominal aorta approach. J Surg Res. 2009; 154: 267-73.

22. Loukogeorgakis SP, Panagiotidou AT, Yellon DM et al. Postconditioning protects against endothelial ischemia-reperfusion injury in the human forearm. Circulation. 2006; 113: 1015-19.

23. Hausenloy DJ, Yellon DM. Preconditioning and postconditioning: underlying mechanisms and clinical application. Atherosclerosis. 2009; 204: 334-41.

24. Tapuria N, Kumar $\mathrm{Y}$, Habib MM et al. Remote ischemic preconditioning: a novel protective method from ischemia reperfusion injury-a review. J Surg Res. 2008; 150: 304-30.

25. Saenz de Tejada I, Angulo J, Cuevas P, Fernandez A, Moncada I, Allona A. et al. Th e phosphodiesterase inhibitory selectivity and the in vitro and in vivo potency of the new PDE-1 inhibitor vardenafi I. Int J Impot Res. 2001;13(5):282-90.

26. Sesti C, Florio V, Johnson EG, Kloner RA. Th e phosphodiesterase5inhibitor tadalafi I reduces myocardial infarct size. Int J Impot Res. 2007;19(1):59-61. 
Tadalafil combined with remote ischemic preconditioning in the prevention of renal ischemia/reperfusion injury.

Azevedo IM, et al.

27. Kukrejia RC, Ockaili R, Salloum F, Yin C, Hawkins J, Das A. et al. Cardioprotection with phosphodiesterase- inhibition - a novel preconditioning strategy. J Mol Cell Cardiol. 2004;36(2):165-73.

28. Rosano GMC, Aversa A, Vitale C, Fabbri A, Fini M, Spera G. Chronic treatment with tadalafi I improves endothelial function in men with increased cardiovascular risk. Eur Urol. 2005; 47(2):214-20.

29. Ko IG, Shin MS, Kim BK et al. Tadalafil improves shortterm memory by suppressing ischemia-induced apoptosis of hippocampal neuronal cells in gerbils. Pharmacol Biochem Behav. 2009; 91:629-35.

30. Zhang Y, Guan DL, Ou TW et al. Sildenafil citrate treatment for erectile dysfunction after kidney transplantation. Transplantation Proc. 2005; 37:2100-3.

31. Ockaili R, Salloum F, Hawkins J et al. Sildenafil (Viagra) induces powerful cardioprotective effect via opening of mitochondrial KATP channels in rabbits. Am J Physiol Heart Circ Physiol. 2002; 283:263-9.

32. Serarslan Y, Yo"nden Z, Ozgiray E et al. Protective effects of tadalafil on experimental spinal cord injury in rats. J Clin Neurosci. 2010; 17:349-52.

33. Oruc $\mathrm{O}$, Inci K, Aki FT et al. Sildenafil attenuates renal ischemia reperfusion injury by decreasing leukocyte infiltration. Acta Histochem. 2010;112:337-44.

34. Reffelmann T, Kloner RA Phosphodiesterase inhibitors: are they cardioprotective? Cardiovasc Res. 2009; 83(2)204-12.

35. Kukreja RC, Ockaili R, Salloum F, Yin C, Hawkins J, Das A, et al. Cardioprotection with phosphodiesterase- inhibition--a novel preconditioning strategy. J Mol Cell Cardiol. 2004; 36(2):204-12.

36. Reffelmann T, Kloner RA. Cardiovascular eff ects of phosphodiesterase inhibitors. Curr Pharm Des. 2006;12(27):3485-94.

37. Lien YH, LaiL W, Silva AL. Pathogenesis of renal ischemia/ reperfusion injury: lessons from knockout mice. Life Sci. 2003;74(5):543-52.

38. Kerendi F, Kin H, Halkos ME, Jiang R, Zatta AJ, Zhao ZQ, Guyton RA, Vinten-Johansen J. Remote postconditioning. Brief renal ischemia and reperfusion applied before coronary artery reperfusion reduces myocardial infarct size via endogenous activation of adenosine receptors. Basic Res Cardiol. 2005; 100:404-12.

39. Heusch G. Molecular basis of cardioprotection: signal transduction in ischemic pre, post-, and remote conditioning. Circ Res. 2015; 116:674-99.

40. Lledo-Garcia E, Rodriguez-Martinez D, Cabello-Benavente R, Moncada-Iribarren I, Tejedor-Jorge A, Dulin E. et al. Sildenafil improves immediate posttransplant parameters in warm-ischemic kidney transplants: experimental study. Transplant Proc. 2007;39(5):1354-56.

41. Friebe A, Koesling D. Regulation of nitric oxide-sensitive guanylyl cyclase. Circ Res. 2003;93(2):96-105. 
Tadalafil combined with remote ischemic preconditioning in the prevention of renal ischemia/reperfusion injury.

Azevedo IM, et al.

42. Chintala MS, Bernardino V, Chiu PJ. Cyclic GMP but not cyclic AMP prevents renal platelet accumulation after ischemia-reperfusion in anesthetized rats. J Pharmacol Exp Ther. 1994;271(3):1203-08.

43. Rosen RC, Kostis JB. Overview of phosphodiesterase inhibition in erectile dysfunction. Am J Cardiol. 2003;92(9):9-18.

44. Guzeloglu M, Yalcinkaya F, Atmaca S, Bagriyanik A, Oktar S, Yuksel O, et al. Th e Benefi cial eff ects of Tadalafi I on renal ischemiareperfusion injury in rats. Urol Int. 2011;96(2):297-303.

45. Gobe G, Johnson DW. Distal tubular epithelial cells of the kidney: Potential support for proximal tubular cell survival after renal injury. Int J Biochem Cell Biol. 2007;39(9):1551-61.

46. Sener G, Tugtepe H, Yuksel M, Cetinel S, Gedik N, Yegen BC. Resveratrol improves ischemia/reperfusion-induced oxidative renal injury in rats. Arch Med Res. 2006;37(7):822-9.

47. Medeiros PJ, Villarim Neto A, Lima FP, Azevedo IM, Leão LR, Medeiros AC. Effect of sildenafil in renal ischemia/reperfusion injury in rats. Acta Cir Bras. 2010;25(6):4905.

48. Jácome DT, Abrahão MS, Morello RJ, Martins JL, Medeiros AC, Montero EF. Different intervals of ischemic preconditioning on small bowel ischemia-reperfusion injury in rats. Transplant Proc. 2009;41(3):827-9. 